\title{
GLOSARIO
} CON don Augusto Orrego Luco, fallecido a los ochen-
ta y seis años de edad, desaparece del escenario de la vida literaria y política de Chile, el último representante de un gran período de la historia nacional. Nacido en 1848, cuando el romanticismo-francés transplantado a América llenaba las conciencias de sus hombres, el doctor Orrego, en su juventud y en su edad madura, se afilió a él, acaso sin quererlo, y permaneció asido a esa corriente en el curso de su larga cuanto fecunda existencia. El romanticismo se había hecho carne en el viejo escritor en todo lo que este concepto tiene de sustantivo en las letras, en la política, en el periodismo y hasta en la manera de ser íntima de un hombre.

Colocado entre un pasado que nos parece sereno y glorioso por una ilusión romántica también, y que nos cuesta ahora comprender en la virtualidad de su sentido humano y en el presente que nos parece trágico, y contradictorio y sin líneas de armonía, porque lo estamos viviendo, bien podría decirse de Orrego Luco que cabalgó entre dos siglos sintiendo de ambos las diferencias espirituales de su estilo. En tal sentido era como el eslabón de una cadena en el tiempo que ataba, por un prodigio, de poder vital, dos épocas históricas, la suya y la nuestra.

Pero de lo que no cabe duda era que pertenecía a su siglo, el siglo XIX, y que el XX no le dió, nada ni transformó tampoco en los más mínimo su estructura intelectual. Como escritor, buscaba en el estilo la música del período, las cadencias de la frase algo cansadas y suaves. Francés en la expresión, fino, delicado en el decir, irónico y amable, sus imágenes resaltan con perfiles de cosas áticas de una proporción severamente clásica. Cuando se le lee parece que uno tiene en sus manos un libro de Paul Saint Victor o Fromentin, acaso este último mayormente a quien tanto se parece en la expresión. Sus páginas que aspiran a una emoción de sentimiento humano que Orrego Luco sabía explotar como gran artista que era, dibujan siempre la figura de 
una mujer. Se complace en retratar la eterna tragedia de los amores contrariados; siente como un placer en estudiar las violencias que levanta esa pasión. La amante de Gambetta, la querida de Augusto Comte, las mujeres de Lord Byron le han arrancado sus más bellos escritos en los cuales la ternura tiene arranques magníficos.

Sin embargo, Orrego Luco, que fué y tuvo toda la contextura del verdadero escritor de vocación, que deja en la historia literaria de Chile un nombre brillante, no produjo muchos libros. Fuera de los de viaje y el intitulado Retratos, sus otros ensayos, de un verdadero mérito que le asegurarán un lugar destacado entre los escritores nacionales de la segunda mitad del siglo XIX, corren desparramados en las hojas de los diarios de que fuera redactor y colaborador, en las revistas que fundó y a las cuales iba tirando casi toda su vasta producción. El mismo no recogía nada ni pareció nunca dispuesto a reunir su obra. Fueron sus amigos los que salvaron muchas de sus más bellas páginas. Escribía, porque sentía un placer en hacerlo, porque algo superior lo impulsaba a ello. Y no tenía tampoco continuidad. Algunos de sus estudios principiados con gran cariño, los dejaba en la mitad: el Byron, por ejemplo, el Lope de Vega es otro caso. Es que en el doctor había el alma de un bohemio. Y lo fué de las letras como un gran señor.

Su obra de periodista-cuando el periodismo en Chile era un género culto para escritores y escritores de pensamiento doctrinario, en la política-fué consagrada a imponer los principios del liberalismo y sabemos que firmaba, a veces, con el pseudónimo de Ruy Blas, no porque él lo dijera, sino porque sus amigos lo estampaban en los libros. La parte principal que tomó en las grandes campañas de opinión del siglo pasado para imponer ideas que hoy día nos parecen que fuera imposible discutir, es considerable y valiosa, y ciertamente que Orrego Luco, cuando se escriba la historia de las ideas políticas en Chile, será recordado con elogio. El político tendrá un lugar en esa historia. Y el médico uno prominente en las ciencias.

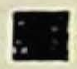

A

L fin-decíamos en una crónica volandera con motivo de la visita de Alfonso Reyes-America Hispana, intenta el pensamiento cordial de la unificación en sus pensadores, en sus artistas, en sus voceros de la expresión pura, limpia de torcidas intenciones, despojada de todo recelo. Con ser Alfonso 
Reyes un diplomático no se entreǵ a la solemne y estirada corporización diplomática que tantas incomprensiones y chascos cuesta a América. Fué siempre, y a despecho de todo, un escritor. La pluma no realiza acaso las jornadas más valiosas del acercamiento y de la comprensión?

La obra de Alfonso Reyes es de las más puras en la expresión americana. Con ser fina no es eso lo que más nos encanta, sino su medularin quietud, su fuerte estructura autóctona. Es lo autóctono en una forma de fina intención clásica. Corren desde hace tiempo por el continente sus obras, lo mismo que esos ríos azules que se internan a través de las montañas y perforan las fronteras convencionales. Esos ríos ondulan y extienden su carga de vitalidad entre una landa y otra; vagan sembrando la voluntad de unión de sus hombres más representativos y arrastran los gérmenes y perfumes de las tierras que cruzan para depositarlos en las vecinas. Tal para nosotros el significado de la obra de Alfonso Reyes.

Los escritores chilenos exteriorizaron con diversos homenajes la simpatía que ya había sabido despertar con su obra literaria, aun antes de que fuera nuestro huésped. Reyes, nos advirtió, en una breve charla que, no quería saber nada de nuestro paisaje típico, sino de sus hombres. Le interesaba lo humano, lo que en la mayor medida, representa la verdadera expresión del carácter de estos pueblos. Lo humano, lo humano, es decir, lo que desde hace tiempo buscamos para entendernos.

Quisiéramos una visión como Reyes sabe hacerlo. Lo decimos porque es sèguro que nos dará su interpretación de lo que ha visto en hombres. Una como adivinación de nuestro destino en la mezcla de los ímpetus desordenados y en las exaltaciones que se atemperan en quietud y en tristeza, y que tan característicos son de nuestra raza, grave y' sarcástica. Saludamos, pues, al maestro del buen decir y del hondo pensar. $-M$.

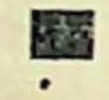

造L

cuarto centenario del nacimiento de Ercilla.-Fué celebrado con exceso de discursos. Tres quedarán. El de Amunátegui Solar que reivindica para España su obra inmensa civilizadora; el de Mariano Latorre que estudió la vida aventurera del poeta con el criterio y el sentido de un artista y la edición popular de La Araucana, editada bajo el auspicio de la Universidad de Chile. 
Una fuente única ha servido a todos esos ensayos. La obra formidable de Medina sobre Ercilla. Ahí han bebido todos. Y sigue siendo su libro sobre el poeta el único guía, la última palabra sobre la vida del literato-soldado. $-F$.

\section{INDICE GENERAL DE LA REVISTA "ATENEA"}

Se encuentra ya en preparación el Indice General de la revista Atenea que abarcará desde el N.॰1 al 100. Este-índice se hará por materias y autores y será de gran interés para nuestros estudiosos de la literatura y para todos los que hayan seguido el desarrollo de nuestra Revista. El material acumulado en las páginas de Atenea representa un bello esfuerzo de la intelectualidad chilena y el índice facilitará de este modo la investigación de las materias que se han tratado en ella, por autores nacionales y extranjeros.

Se ruega a los escritores nacionales e iberoamericanos enviar sus obras a esta Revista, en cuyas páginas daremos cuenta en notas bibliográficas y críticas.

\section{Direccion para estos envíos:}

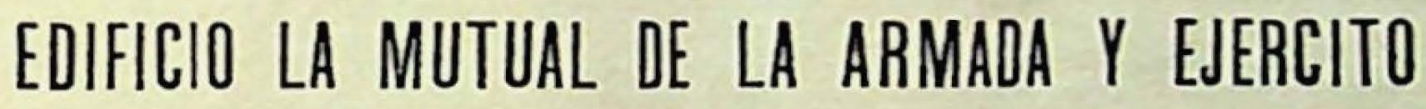

2..$^{\circ}$ PISO - OFICINA $8=$ SANTIAGO DE CHILE 